\title{
DIÁLOGO, CONSCIÊNCIA COSMOPOLITA E DIREITOS HUMANOS:
}

\section{OS RUMOS E LIMITES DAS LUTAS IDENTITÁRIAS NO MUNDO CONTEMPORÂNEO}

\section{DIALOGUE, COSMOPOLITAN CONSCIENCE AND HUMAN RIGHTS: THE BEARINGS AND LIMITS OF IDENTITARIAN STRUGGLES IN THE CONTEMPORARY WORLD}

\author{
EDUARDO C. B. BITTAR ${ }^{1}$
}

\begin{abstract}
RESUMO: O presente artigo investiga a correlação entre os termos cultura, civilização e cidadania, para afirmar a importância de pensá-los criticamente, à luz dos desafios políticos contemporâneos. Relê o problema das lutas identitárias e a retomada das raízes das culturas, especialmente em direitos humanos, para apontar caminhos para a consciência cosmopolita, com base nas reflexões da teoria do discurso de Jürgen Habermas.

PALAVRAS-CHAVE: Cidadania Cosmopolita; Cultura Pós-nacional; Diálogo.
\end{abstract}

ABSTRACT: This article intends to investigate the terms culture, civilization and citizenship, to discuss the importance of thinking them, under the lights of the contemporary political devices. It intends to read the identity struggles and the radicalization of the culture politics, especially in human rights, to point some ways to the cosmopolitan consciousness, based on the theory of discourse of Jürgen Habermas.

KEYWORDS: Cosmopolitan Citizenship; Post-national Culture; Dialogue.

SUMÁRIO: Introdução; 1. A Ideia de Cultura e o Processo Civilizador Moderno; 1.1 O Processo Civilizador, Identidade pela Cultura e a Formação do Estado-nação; 1.2 Os Riscos da Barbárie como Fruto da Civilização e o Nacionalismo Moderno; 1.3 Os Riscos do Relativismo Absoluto e a Retomada Política da Cultura das Identidades; 2. Diálogo e Cosmopolitismo: Desafios da cultura pós-nacional; Conclusões; Bibliografia.

\footnotetext{
Artigo recebido em 01.12.2011. Pareceres emitidos em 11.09.2012 e 07.01.2013.

Artigo aceito para publicação em 10.03.2013.

${ }^{1}$ Livre-Docente e Doutor, Professor Associado do Departamento de Filosofia e Teoria Geral do Direito da Faculdade de Direito da Universidade de São Paulo - SP, nos cursos de Graduação e Pós-graduação. Professor e Pesquisador do Mestrado em Direitos Humanos do Centro Universitário FIEO (Osasco - SP). Pesquisador de Produtividade N-2 do CNPq. ecbbittar@gmail.com
} 
SUMMARY: Introduction; 1 . The Idea of Culture and the Modern Civilizational Process; 1.1 The Civilizational Process, Culture by Identity and the Establishment of the Nation-state; 1.2 The Risks of Barbarism as Results of Civilization and Modern Nationalism; 1.3 The Risks of Absolute Relativism and the Political Revival of the Culture of Identities; 2. Dialogue and Cosmopolitanism: Challenges of post-national culture; Conclusions; Bibliography.

\section{INTRODUÇÃO}

A pesquisa sobre os desafios cosmopolitas, num cenário de crise global, é uma preocupação contemporânea de grave significação política, e que incita a uma necessária intersecção com as interfaces da filosofia política, dos direitos humanos e da antropologia. ${ }^{2}$ A comunidade internacional, desafiada a viver contextos globais comuns, em momento de desarranjos econômicofinanceiros decorrentes de uma crise global, vê-se pressionada a pensar seus dilemas históricos e desafios, tendo por pano de fundo uma disfunção paradigmática que envolve o desafio da compreensão das heranças decorrentes das ideias de 'cultura' e 'civilização', e as disputas que se dão neste terreno, tendo-se como pano de fundo a crise da modernidade, e necessidade de revisão de seu projeto e sentido atuais. Se a cena global abriu-se ao século XXI sob os holofotes dos eventos do 11 de setembro de 2001, e as tensões entre 'Oriente' e 'Ocidente' foram explicitadas aos olhos de uma audiência mundialmente midiatizada, ${ }^{3}$ ocorre que as reações ao 'modo de vida moderno' têm gerado fortes acirramentos de retorno à cultura, à religião, à identidade, à etnia, à nação, como apelos de busca de auto-identificação, reações de busca de segurança num mundo incertezas generalizadas. ${ }^{4}$

Diante de um quadro global de desnorte e insegurança, considerando-se a crise financeira e os atuais desafios impostos pelas mudanças climáticas, é certo que a saída mais imediata é aquela em que se aponta para o 'culpado'

\footnotetext{
${ }^{2}$ Isso porque a questão da cultura está profundamente imbricada com questões de alta significação para a órbita do direito, e, especialmente, dos direitos humanos. A respeito, vide Kant de Lima, Antropologia e Direito Humanos, $\mathrm{n}^{\circ}$ 03, 2001; Schritzmeyer, Nossos Muros e os dos Outros, in Antropologia Extramuros: novas responsabilidades sociais e política dos antropólogos, 2008, p 173-178; Mercier, História da Antropologia, s.d.; Eagleton, A Idéia de Cultura, 2005; Grossi, Antropologia e Direitos Humanos, in Antropologia e Direitos Humanos, nº 04, p. 07- 11.

3 "Talvez o dia 11 de setembro pudesse ser chamado de o primeiro acontecimento histórico mundial no sentido mais estrito: o impacto, a explosão, o lento colapso - tudo o que não era mais Hollywood, mas, na verdade, era uma realidade medonha, teve lugar literalmente diante da testemunha ocular universal de um público global" (Habermas, Fundamentalismo e terror, in Filosofia em tempo de terror (Giovanna Borradori, org.), 2004, p. 40).

${ }^{4}$ A respeito da reflexão sobre a situação dos direitos humanos numa época de insegurança, consulte-se Bittar, Tosi (orgs.), Democracia e Educação em Direitos Humanos num época de Insegurança, UFPB, ANDHEP, SEDH, 2008. Sobre o teme, em específico, consultem-se as contribuição de Samuel Huntignton, em The clash of civilizations, de onde se pode extrair a seguinte afirmação: "Os povos e as nações estão tentando responder à pergunta mais elementar que os seres humanos podem encarar: quem somos nós?" (Huntington, O Choque de Civilizações e a Composição da Ordem Mundial, 1997, p. 20).
} 
da insegurança mundial. ${ }^{5}$ Daí a tendência sempre efusiva ao acirramento de tensões globais, que também ganham reforço e feição nas tensões identitárias. Por isso, o 'sempre delicado equilíbrio internacional' abre-se como um desafio à nova política pós-nacional, ao gerenciamento dos poderes globais, aos movimentos sociais ligados à representação de interesses globais, à comunidade internacional como destinatária dos efeitos desse processo de transformações. ${ }^{6}$

De modo mais específico, constata-se que a contraposição cultural, o xenofobismo crescente, a limitação à circulação de pessoas, a busca de segurança nacional, forjada na base da blindagem das fronteiras, as leis proibitivas em face das tradições e dos hábitos islâmicos, são estes alguns dos conflitos recorrentes na cena global, e que têm exposto um pouco quadro dos problemas a serem considerados como parte de um conjunto de desafios políticos ao longo da história do presente. ${ }^{7}$

\section{A IDEIA DE CULTURA E O PROCESSO CIVILIZADOR MODERNO}

O conceito de cultura é um dos muitos frutos da árvore da modernidade. Ainda que este conceito seja de alta complexidade, se percebe em seu estudo e pesquisa um importante referencial para a discussão do tema da 'cultura cosmopolita'. A ciência que se dedica a este perfil de conhecimento, o conhecimento do Homem e ao estudo das culturas, a 'Antropologia', é também fruto deste processo de afirmação do iluminismo. A antropologia somente ganhou estatuto epistemológico específico na história interna do evolver da modernidade. $^{8}$ O próprio termo 'antropologia' é uma criação do século XVIII,

\footnotetext{
5 "Classificar as vítimas da furiosa globalização dos mercados de bens e financeiros como, acima de tudo, uma ameaça à segurança, e não como pessoas que necessitam de ajuda e dignas de compensação pelos danos provocados em suas vidas, tem óbvias utilidades. Alivia os escrúpulos e recompensa os remorsos éticos. Afinal, está se lidando com inimigos que "odeiam os nossos valores" e não suportam nos ver, pessoas comuns, por nossa determinação de viver em liberdade e na democracia. Isso ajuda a desviar os fundos que poderiam ser usados para reduzir as disparidades e esvaziar as animosidades que estas produzem, de modo a alimentar a indústria de material bélico, as vendas de armas e os lucros dos acionistas, e assim a melhorar as estatísticas domésticas na área do emprego e aumentar o gradiente de satisfação do eleitorado" (Bauman, Europa: uma aventura inacabada, 2006, p. 34-35).

${ }^{6}$ A questão está claramente posta nas pesquisas historiográficas de Peter Demant: "O que tal tensão nos diz sobre o Oriente Médio, a Europa, e o relacionamento entre ambos? Os 15 ou 20 milhões de muçulmanos europeus constituem um inassimilável 'Oriente Médio fora do Oriente Médio' - ou a vanguarda potencial de uma aproximação (ao invés de choque) de civilizações?" (Demant, Os Dilemas dos Muçulmanos na Europa, in Panorama da Conjuntura Internacional, 2008, p. 02).

${ }^{7}$ A questão está muito distante de ter uma solução definitiva, e expõe a fragilidade do tema e da condição muçulmana na Europa: "As ansiedades se traduzem em movimentos xenófobos que mobilizam o medo da competição por empregos escassos ou sobre incompatibilidade cultural convenientemente esquecendo o envelhecimento demográfico o continente, e sua conseqüente necessidade de migrantes. Cerca de metade dos europeus hoje associa 'muçulmano' com 'extremista' " (Id. Ibid.).

8 "Tais estudos iniciaram-se, enquanto projetos científicos, no bojo do positivismo das últimas décadas do século XIX, quando outras ciências sociais, também inspiradas em modelos das bem sucedidas ciências físicas e naturais, firmavam-se academicamente e ganhavam cátedras em algumas das principais universidades da Alemanha, Grã-Bretanha, França e Estados Unidos"
} 
sendo o termo 'etnografia' criado no século XIX, e a primeira cátedra de Antropologia é criada na Universidade de Paris, em 1855. É com base no positivismo moderno, ao longo do século XIX, que se permitirá inscrever na curiosidade ultra-marina uma forma de manifestação da curiosidade mundana que, na Europa, se traduziu na forma de expressão de uma curiosidade em relação às outras culturas, ao exótico, ao fantástico, ao diferente. ${ }^{9}$ Não por outro motivo, a 'marca de nascimento' do estatuto científico da Antropologia no mundo ocidental esteve atrelada às forças do imperialismo. A discussão da relação 'civilização' versus 'barbárie' marca o cenário de nascimento da ciência que estuda o 'Homem' e suas manifestações culturais. ${ }^{10}$

Se o termo 'cultura' pode ser visto como um dos dois ou três termos mais complexos do vocabulário, como afirma Terry Eagleton, é necessário que se veja atrás do termo 'cultura' também uma outra complexidade histórica. Atrelada à história deste termo está também o nascimento da ideia de 'identidade nacional'. Isto porque, se considerada a importância do termo 'cultura' para a modernidade, a 'cultura' como "...o complexo de valores, costumes, crenças e práticas que constituem o modo de vida de um grupo específico", ${ }^{11}$ ele se torna um elemento de fundamental importância para a auto-afirmação das comunidades, e, por isso, um forte peso a favor da lógica de identificação sob o bastião do Estado-nação. Ela é, neste sentido, um Hintergrund, como afirma Marcuse: “...cultura é entendida como o complexo específico de crenças religiosas, aquisições, tradições, etc. que configuram o 'pano de fundo' (Hintergrund) de uma sociedade". ${ }^{12}$ A 'cultura' é capaz de transmitir, entre gerações, identidades como categorias da convivência que

(Schritzmeyer, Ana Lúcia Pastore. Antropologia e Educação em Direitos Humanos, in Educação e Metodologia para os Direitos Humanos (Bittar, Eduardo C. B., org.), 2008, p. 119).

${ }^{9}$ Sobre a correlação entre exotismo, classificação e estudo dos 'tipos humanos', leia-se: "Sem dúvida, graças a explicações comparativas, hierarquizantes e valorativas referentes aos graus de evolução dos grupos humanos, na melhor das hipóteses, os 'selvagens' eram classificados como exóticos e dignos de compor vitrines em Exposições Universais, como a de 1889, em Paris (Darmon, 1991: 11), bem como de suscitar projetos que visavam preservar seu estado primitivo. Na pior das hipóteses, intervenções de todo gênero se justificavam em nome da 'aceleração de seu progresso'." (Schritzmeyer, Ana Lúcia Pastore. Antropologia e Educação em Direitos Humanos, in Educação e Metodologia para os Direitos Humanos (Bittar, Eduardo C. B., org.), 2008, p. 121). Sobre o surgimento e a significação dos termos bárbaro e selvagem, vide Lévi-Strauss, Antropologia Estrutural Dois, 4. ed., 1993, p. 333-334.

${ }^{10}$ Para todo o parágrafo, conferir Eagleton, A Idéia de Cultura, 2005, p. 54 e Bauman, Vida Líquida, 2007, p. 71-90. Ainda, a respeito do tema, vide Said, Orientalismo: o Oriente como invenção do Ocidente, 1990, Mercier, História da Antropologia, s.d., Oliveira, A Questão Étnica: qual a possiblidade global?, in As Dimensões Culturais da Transformação Global, 2001, bem como, Elias, O Processo Civilizador: uma história dos costumes, v. I, 1994, e, v. II, 1993.

${ }^{11}$ Eagleton, A Idéia de Cultura, 2005, p. 54. Marcuse a essa definição se reporta em um de seus estudos sobre o tema: "Parto da definição de cultura dada pelo Webster, segundo a qual cultura é entendida como o complexo específico de crenças religosas, aquisições, tradições, etc. Que configuram o pano de fundo (Hintergrund) de uma sociedade" (Marcuse, Comentários para uma Redefinição de Cultura, in Cultura e Sociedade, 1998, p. 153).

${ }_{12}$ Marcuse, Comentários para uma Redefinição da Cultura, in Cultura e Psicanálise, 3. ed., 2001, p. 69. 
são assimiladas inconsciente e primariamente pelos indivíduos submetidos ao processo de socialização, a ponto de se reconhecerem por evidências calcadas numa experiência comum.

Ainda, o nascimento etimológico do termo 'cultura' revela algo curioso, na medida em que descende do latim colere, que significa cultivar. Ora, dentro da metáfora do cultivo, da produção, da arte de arar a terra, estão contidos os gérmens identificadores da significação da ideia de cultura, que rapidamente se associará a esta outra ideia, qual seja, a ideia de 'civilização', oposta àquela outra da 'barbárie'. ${ }^{13}$ A oposição entre 'civilização' e 'barbárie' será uma preocupação central dos estudos da Antropologia, não deixando de gerar sérias preocupações filosóficas, e, exatamente por isso, compreender suas tensões não é tarefa simples. Essa aproximação entre os termos 'civilização' e 'cultura', consideradas as ambiguidades recíprocas, traduz o mesmo grau de complexidade que o só termo 'cultura' já sintetiza.

O estado do desenvolvimento das ciências, dos costumes, dos hábitos sociais, da técnica permitem dar contornos ao termo 'civilização', e traduzir as exigências de um 'mundo civilizado', em oposição à 'barbárie', como constata Norbert Elias, em seu estudo seminal sobre o 'processo civilizador europeu'. ${ }^{14}$ O que se percebe, portanto, é que o termo 'cultura' passa a figurar, desde os primórdios de sua introdução no vocabulário culto europeu, um termo evocativo de 'civilização', oposto, portanto, a todo primitivismo contido na ideia de 'barbárie'. ${ }^{15}$ Assim, opõem-se, na história da modernidade, as nações civlizadas em seu empreendimento civlizador, e as nações ainda não desenvolvidas, e, por isso, passíveis de influenciação culturalizadora nos padrões do civilizador. Por isso, para Levi-Strauss, “...o bárbaro é inicialmente o homem que acredita na barbárie". ${ }^{16}$ A barbárie somente existe com base num contra-ponto, indicado pelo termo civilização, daí seu uso político tornar-se legitimador de processos de dominação neo-colonialista. Em particular, a língua

\footnotetext{
${ }^{13}$ Cf. Eagleton, A Idéia de Cultura, 2005, p. 54-57.

${ }^{14}$ Sobre a ambiguidade daquilo que o termo civilização quer representar e sua espectro semântico: "O conceito de civilização refere-se a uma grande variedade de fatos: ao nível da tecnologia, ao tipo de maneiras, ao desenvolvimento dos conhecimentos científicos, às idéias religiosas e aos costumes" (Elias, O Processo Civilizador: uma história dos costumes, v. I, 1994, p. 23).

${ }^{15}$ A relação de preconceito cultural, a identificação do nascimento da ideia de civilização da modernidade, bem como a justificação da dominação, do discurso filosófico-teológico do início da modernidade parecem com clareza das reflexões de Sepúlveda, como destaca em aprofundada análise Giuseppe Tosi: "Sepúlveda inaugura assim o discurso justificador que será depois apropriado pelos ideólogos da colonização e da escravidão das potências coloniais européias. $\mathrm{Na}$ sua obra encontramos os germes daquilo que será a ideologia dominante da modernidade, ou seja, a da superioridade da civilização ocidental "que tem direito de dominar sobre os semibárbaros e os não-civilizados"' (Tosi, Guerra e Direito no Debate sobre a Conquista da América, in Verba luris: Anuário da Pós-Graduação em Direito, Ano 5, nº 05, p. 277-320, jan./dez. 2006, p. 287).

${ }^{16}$ Sobre o surgimento e a significação dos termos bárbaro e selvagem, vide Lévi-Strauss, Antropologia Estrutural Dois, 4. ed., 1993, p. 335.
} 
alemã designa por Kultur (civilisation, no francês) ${ }^{17}$ algo que tem a ver com os produtos, e por Zivilisation o processo histórico comportado na longa trajetória da identidade de um povo, para a qual refluem as ideias de polidez e civilidade (politesse e civilité) ${ }^{18} \mathrm{Na}$ história da modernidade, o termo civilização, portanto, jogou dois papéis importantes, sendo um primeiro, de identificação de distintos costumes comuns, e, um segundo, relativo a formas de expressão de usos político-ideológicos justificadores da dominação. A história da modernidade se afirma contando com a correlação destes termos.

O conceito atual de civilização remete a um uso, ainda que complexo, específico, e permite designar agrupamentos culturais identificadores. O conceito de civilização, e ainda, a identificação das civilizações, é tarefa de complexo enfrentamento, porém, seguindo a lição de Samuel Huntington, pode-se afirmar que uma civilização é "... o mais alto agrupamento cultural de pessoas e o mais amplo nível de identidade cultural que as pessoas têm aquém daquilo que distingue os seres humanos das demais espécies. Ela é definida por elementos objetivos comuns, tais como língua, história, religião, costumes, instituições e pela auto-identificação subjetiva das pessoas". ${ }^{19}$

A força ideológica da identidade é tamanhamente constitutiva, que se pode perder a ideia de que se compartilha um mundo com outros seres humanos, iguais no gênero, para fazer prevalescer a expressão de uma religião sobre a outra, de uma verdade sobre a outra, de um padrão de costumes sociais sobre outros, a ponto de se gerarem graves conflitos, genocídios, perseguições políticas, extermínio racial, promovendo-se guerra e intolerância. ${ }^{20}$ A força ideológica contida na identidade pode, neste sentido,

\footnotetext{
17 "O conceito francês de civilisation, exatamente como o conceito alemão correspondente de Kultur, emergiu nesse movimento de oposição na segunda metade do século XVIII. Seu processo de formação, função e significado foram tão diferentes dos implícitos no conceito alemão como as circunstâncias e costumes da classe média nos dois países. Não deixa de ser interessante observar como o conceito francês de civilisation, tal como surge inicialmente na literatura, assemelha-se ao conceito ao qual muitos anos depois Kant opôs seu conceito de Kultur. A primeira evidência literária da evolução do verbo civiliser para o conceito de civilisation é encontrada, de acordo com descobertas modernas, na obra de Mirabeau, o pai, na década de 1760" (Elias, O Processo Civilizador: uma história dos costumes, v. I, 1994, p. 54).

18 "Civilização descreve um processo ou, pelo menos, seu resultado. Diz respeito a algo que está em movimento constante, movendo-se incessantementre para frente. O conceito alemão de Kultur, no emprego corrente, implica uma relação diferente com movimento. Reporta-se a produtos humanos que são semelhantes a flores do campo, a obras de arte, livros, sistemas religiosos ou filosóficos, nos quais se expressa a individualidade de um povo. O conceito de kultur delimita" (Id., p. 24-25). Mais adiante, pode-se ler, este importante trecho: "Duas idéias se fundem no conceito de civilização. Por um lado, ela constitui um contraconceito geral a outro estágio da sociedade, a barbárie. Este sentimento há muito permeava a sociedade de corte. Encontrara sua expressão aristocrática de corte em termos como politesse e civilité" (Id., p. 62).

${ }^{19}$ Huntington, O Choque de Civilizações e a Composição da Ordem Mundial, 1997, p. 47-48.

${ }^{20}$ Esta é a ideia de Huntington: "Entretanto, de todos os elementos objetivos que definem as civilizações, o mais importante geralmente é a religião, como enfatizaram os atenienses. Em larga medida, as principais civilizações na História da Humanidade se identificaram intimamente com
} 
'localizar' o indivíduo no mundo e na história, na origem e no grupo, mas pode igualmente cegá-lo para enxergar a diferença e a alteridade da outra civilização. $\mathrm{Na}$ visão de Huntington, dentre os diversos elementos objetivos que jogam sentido dentro da ideia de civilização (língua, história, costumes, religião e instituições), a religião é aquele elemento que maior força unificadora possui na criação de laços entre os indivíduos. Por isso, hodiernamente, as quatro principais religiões (cristianismo, islamismo, hinduísmo, confucionismo) conferem definição às grandes civilizações vigentes e existentes, a partir de onde pode-se constituir um 'mapa de observação' das civilizações contemporâneas. A força unificadora da religião exerce-se, em grande parte, apesar das distâncias, apesar dos territórios dos Estados-nação, apesar das diferenças político-partidárias, apesar das diferenças linguísticas e culturais, sendo, por isso, um elemento objetivo capaz de aglutinar populações enormes sob o signo de uma mesma civilização. ${ }^{21}$

Ainda que problemática, uma cartografia das civilizações no globo, na visão de Samuel Huntington, obedece aos seguintes principais eixos de expressão: a civilização sínica (remonta a 1500 a. C., e que envolve a China e demais países de influência chinesa do sudeste asiático, Coréia e Vietnã); a civilização japonesa (remonta a 100 d. C.); a civilização hindu (remonta a 1500 a. C., e que envolve mais do que simplesmente a Índia como Estadonação); a civilização islâmica (remonta ao século VII d.C., envolvendo as culturas árabe, africana, turca, malaia e persa, num cadinho cultural que vai muito além da península arábica); ${ }^{22}$ a civilização ortodoxa (centrada na divergência com a cristandade ocidental e na Rússia como pólo conservador e dispersor desta identidade); a civilização ocidental (cuja conformação se dá pela sua distribuição entre a Europa e as Américas); a civilização latinoamericana (apesar das enormes polêmicas entre os historiadores, pode ser considerada uma civilização destacada das demais do Ocidente, em função de peculiaridades que Ihe são próprias); a civilização africana (cuja polêmica na literatura cria divergências para a identificação de sua própria natureza como civilização destacada). ${ }^{23}$ Considerando as inúmeras dificuldades classificatórias, aponta-se para a ideia de que cada civilização carrega um caleidoscópio de fatores de diversas qualidades como elementos de integração e formação de um mundo da vida (Lebenswelt), de cujo reconhecimento se nutrem seus membros.

as grandes religiões do mundo povos que compartilham etnia e idioma podem, como no Líbano, na antiga lugoslávia e no Subcontinente indiano, massacrar-se uns aos outros porque acreditam em deuses diferentes" (Id., p. 46-47).

${ }^{21}$ Cf. Huntington, O Choque de Civilizações e a Composição da Ordem Mundial, 1997, p. 54.

22 Neste ponto, pode-se verificar a conrdoância de Peter Demant, quando afirma: "O mundo muçulmano tem hoje um alcance global e, mais do que uma religião, é uma civilização" (Demant, O Mundo Muçulmano, 2004, p. 77).

${ }^{23}$ Cf. Huntington, O Choque de Civilizações e a Composição da Ordem Mundial, 1997, p. 50-52 e 54-55. 


\subsection{O Processo Civilizador, Identidade pela Cultura e a Formação do Estado-nação}

$\mathrm{Na}$ história da modernidade, em torno das ideias de cultura e de civilização se reúne a ideia de 'cidadania', um dos elementos-chave da conformação dos Estados-nação em sua relação com os seus membros, os cidadãos. A 'cidadania', como condição de quem porta um status de pertencente a um Estado-nação, é uma ideia que absorve em seu interior a relação entre os termos 'civilização' e 'cultura'. Os cidadãos como 'parceiros do direito' serão, antes, identificados pelos traços da língua comum, das tradições e costumes, dos laços consaguíneos, da identidade étnica e cultural, mas se farão iguais no direito. Significando pertença a um Estado-nação, a ideia de 'cidadania' se confundia com a ideia de aceitação a uma ordem jurídico-formal de reconhecimento a partir do direito, de um povo unificado e pacificado, para cuja tutela legal implicava o pertencimento a uma unidade nacional civilizada e ordeira. ${ }^{24}$ Assim, modernamente, os juristas identificam 'cidadania' com pertença à unidade de um Estado-nação. Em Direito e democracia, Habermas trata do tema, afirmando que "...a "cidadania", "citoyenneté" ou "citizenship" teve, durante longo tempo, apenas o sentido de nacionalidade ou de pertença a um Estado; só ultimamente o conceito foi ampliado no sentido de um status de cidadão envolvendo direitos civis. A pertença a um Estado regula a subordinação de pessoas sob um Estado, cuja existência é reconhecida pelo direito internacional". ${ }^{25}$

Por isso, num certo sentido, quando empregado para designar a ideia de identidade coletiva, o termo 'cultura' indica a existência de uma 'vida compartilhada', o que pode ser considerado um tema de fundamental importância para a discussão sobre o próprio surgimento de um aspecto central da modernidade: o nascimento dos Estados-nação e o estatuto do 'cidadão nacional'. Nesse sentido específico, a 'cultura' comum que unifica os 'cidadãos sob um Estado-nação', onde o termo 'nação', modernamente, é evocativo da ideia de uma origem comum aos membros de um mesmo corpo político, implicando a ideia de um etnonacionalismo. ${ }^{26}$ Os conceitos de Kultur e Zivilisation, na análise sociológica de Norbert Elias, estão atrelados

\footnotetext{
${ }^{24} \mathrm{Na}$ leitura de Norbert Elias, essa associação também é clara: "O processo de civilização do Estado, a Constituição, a educação e, por conseguinte, os segmentos mais numerosos da população, a eliminação de tudo o que era ainda bárbaro ou irracional nas condições vigentes, fossem as penalidades legais, as restrições de classe à burguesia ou as barreiras que impediam o desenvolvimento do comércio - este processo civilizador devia seguir-se ao refinamento de maneiras e à pacificação interna dos país pelos reis" (Elias, O Processo Civilizador: uma história dos costumes, v. I, 1994, p. 62).

${ }^{25}$ Habermas, Direito e Democracia, II, 2003, p. 285.

${ }^{26}$ Cf. Habermas, Inclusão: integrar ou incorporar?: sobre a relação entre nação, Estado de Direito e democracia, in Revista Novos Estudos, 2004, p. 99. Também: "O que se menciona com menos freqüência, porém, embora não o mereça, é que a modernidade também endeusou e encantou a nação, a nova autoridade - e, assim, por procuração, as instituições feitas pelo homem que afirmavam falar e agir em seu nome" (Bauman, Vida Líquida, 2007, p. 61).
} 
a este processo de afirmação da 'identidade nacional': "As auto-imagens nacionais representadas por conceitos como kultur e civilização assumem formas muito diferentes. Por mais diferente que seja a auto-imagem dos alemães, que falam com orgulho em sua civilização, todos consideram axiomático que a sua é a maneira como o mundo dos homens, como um todo, quer ser visto e julgado. O alemão pode, quem sabe, tentar explicar a franceses e ingleses o que entende pelo conceito de kultur. Mas dificilmente pode comunicar o mínimo que seja do meio formativo nacional específico e valores emocionais axiomáticos que para ele a palavra reveste". ${ }^{27} \mathrm{Com}$ base em costumes locais, língua comum, território e hábitos compartilhados, o 'nacionalismo' tornou-se a bandeira do processo de formação da 'cultura nacional moderna'.

Assim, o que se chama de 'nação' é mais uma construção do que um decurso 'natural', podendo-se afirmar que o termo é re-apropriado das tradições latinas (natio) para significar a forma de consagração da forma de vida moderna (economia de mercado, dominação legal-burocrática, racionalização do mundo da vida, desenvolvimento do aparato técnico-científico, formação através da escolarização) e a consolidação da dessacralização da cultura. ${ }^{28}$ Os usos modernos de natio aparecem ligados às noções modernas de povo (populus) e soberania. Em Direito e democracia, Habermas historia a questão, ao afirmar: "A história do surgimento do Estado nacional reflete-se na história do conceito "nação". Entre os romanos, "natio" é a deusa da origem e do nascimento. Ao contrário da "civitas", a "natio", do mesmo modo que "gens" e "populus", refere-se a populações (muitas vezes "selvagens", "bárbaras" ou "pagãs") que ainda não se organizaram em associações políticas. Segundo este uso clássico, as nações são comunidades que têm a mesma origem, sendo integradas, do ponto de vista geográfico, através de colônias e da vizinhança, e, do ponto de vista cultural, através da linguagem, dos costumes e de tradições comuns; porém, ainda não se encontram integradas politicamente através de uma organização estatal. A "nação" mantém este significado durante a Idade Média. No século XV, ela se introduz nos idiomas populares. O próprio Kant afirma: "A massa que se reconhece unida através da descendência comum, formando uma totalidade civil, deve ser chamada 'nação' (gens)". Porém, no início da modernidade, surge um novo uso: a nação como titular da soberania". As corporações representam a "nação face ao rei". E desde meados do século XVIII, ambos os significados, o de "nação", no sentido de uma comunidade que tem a mesma origem e o de "povo de um Estado", se entrelaçam. Com Sieyès e a Revolução Francesa, a "nação" se transforma na fonte da soberania do Estado. A partir daí, cada nação deve ter o direito à autodeterminação política. O complexo étnico cede, pois, o lugar à comunidade democrática intencional". ${ }^{29}$

\footnotetext{
${ }^{27}$ Elias, O Processo Civilizador: uma história dos costumes, v. I, 1994, p. 25.

${ }^{28}$ Cf. Rochlitz, Habermas: o uso público da razão, 2005, p. 119-120.

${ }^{29}$ Habermas, Direito e Democracia, II, 2003, p. 282.
} 
Em verdade, a identidade criada sob o termo 'nação', na modernidade, num primeiro momento, se dá como fermento para a formação de uma cidadania que unifica e reúne os indivíduos em torno de objetivos comuns, contidos no regime comum do direito, e unificado nas leis do legislador racional e nacional. Porém, num segundo momento, o nacionalismo é conduzido a significar um elemento de contradição e oposição com relação ao outro. O imperialismo expansionista encontra seus elementos de afirmação nesta ideia, e, mais recentemente, a ideia do 'nacionalismo integral' cria a supremacia étnico-racial que auto-define a condição de pertencentes a uma nação permite a expansão de doutrinas racistas e xenofóbicas, reaparecendo com toda força nas expressões dos totalitarismos, no início do século XX. Em Diagnóstico do tempo, Habermas afirma: "Os Estados nacionais clássicos e os que surgiram dos movimentos de Risorgimento conviveram, de modo mais ou menos disfarçado, com tais contradições. Entretanto, o equilíbrio precário foi rompido pelo nacionalismo integral, incorporado em figuras tais como Mussolini e Hitler. A partir deste momento, o egoísmo nacional foi desligado totalmente das origens universalistas do Estado constitucional democrático. O elemento particularista que, até então, tinha sido mais ou menos domado, soltou-se totalmente, configurando-se na Alemanha nazista na ideia da supremacia racial do próprio povo. Conforme já salientamos, isso fortaleceu a retaguarda de uma mentalidade, sem a qual não teria sido possível definir, com o auxílio de uma pseudociência, as categorias de inimigos internos e externos, a serem exterminados em massa. Na Alemanha, o choque que se seguiu à exaltação fez com que as continuidades da história nacional, produzidas narrativamente se rompessem, mesmo que, no início, isso tenha ocorrido na forma de uma simples defesa e da exclusão do período ocupado negativamente. Num prazo mais longo, no entanto, esse choque também desencadeou uma irrupção da reflexão na consciência histórica pública, sacudindo as auto-evidências de uma identidade coletiva cunhada pelo nacionalismo". ${ }^{30}$

Por isso, se a ideia de nação tem um sentido, na reequipagem da vida moderna, para a consolidação de suas formas-estrutura, sem dúvida, o extremismo que decorre destas concepções, conduz a cultura moderna a um paradoxo. Da 'civilização' brota a 'barbárie moderna', e, da 'cultura civilizada', moderna, técnica e racional, vai nascer Auschwitz, a 'barbárie orquestrada pelo Estado-nação', em nome do nacionalismo imperialista. Assim, se a formação do 'Estado-nação', com vistas à organização do direito moderno unificador, a 'nação', termo-síntese para a auto-identificação dos cidadãos como parceiros de uma mesma experiência cultural e na defesa de limites territoriais específicos, deve ser considerada uma ideia historicamente importante, mas cujos riscos do nacionalismo integral, já expostos, sempre rondam o espírito de organização da vida contemporânea. Por isso, a consciência

\footnotetext{
${ }^{30}$ Habermas, Diagnósticos do Tempo: seis ensaios, 2005, p. 112.
} 
da dialética histórica da modernidade deve estar presente na configuração da reflexão que funda o futuro, quando a ideia comparece como prospectivamente perigosa. Tendências contemporâneas de acirramento destes sentimentos apenas tornam mais explosiva a atmosfera do convívio global.

O riscos atuais são os de um retorno a formas pré-modernas de conformação dos arranjos sociais, fundados em arcanos culturais, identitários, étnico-raciais, religiosos, que muitas vezes podem traduzir novos fanatismos e expressões de dominação ideológica. ${ }^{31}$ Sua valia fica registrada como uma etapa de um processo histórico que se consolidou, e que, portanto, serve de referencial para a identificação da luta por critérios de separação entre as esferas territoriais de um Estado e de outro. No entanto, a ideia de uma justiça fundada no nacionalismo parece começar a encerrar o seu ciclo de afirmação, para ceder lugar à cultura de uma justiça pós-nacional, esta fundada na experiência da progressiva e inevitável união dos povos em torno de desafios comuns, para além dos limites físicos que definem as marcas do território nacional.

\subsection{Os Riscos da Barbárie como Fruto da Civilização e o Nacionalismo Moderno}

A necessidade de conformação de uma personalidade cosmopolita responde à ideia de que a integração dos povos é um processo inevitável na relação entre os povos. Esta ideia também conduz à crítica dos resultados objetivos da 'doutrina do nacionalismo integral', base do genocídio à população judaica européia, donde emergirá a formação do universalismo contemporâneo da Declaração Universal de $1948 .^{32}$ Por isso, no atual contexto, a cultura pós-nacional reclama a relativização da ideia de 'nação', sem o que não é possível a formação de uma consciência de que a humanidade sobrevive a partir de laços que suplantam a conformação das identidades locais, culturais, regionais, nacionais. Consideradas, especialmente, as sociedades multiculturais existentes, como a Suíça, o Brasil e os Estados Unidos, percebe-se que a ideia de 'cultura comum' não é uma condição para a existência de uma comunidade de parceiros no direito e nas instituições políticas.

É por isso que a cultura pós-nacional reclama a dispersão da consciência de que cada indivíduo 'é no outro cosmopolita', parceiro do mundo, parceiro

\footnotetext{
${ }^{31}$ Fica evidenciada a auto-reflexão crítica promovida pelo mundo árabe. Nesse sentido, as importantes reflexões do filósofo marroquino Abed Al-Jabri: "De fato, o mundo árabe sofre atualmente da hegemonia de um outro tipo de irracionalismo, totalmente diferente do irracionalismo da Europa, ponto de chegada do racionalismo europeu: uma irracionalidade medieval, com todas as conseqüências que ela implica, e em especial a persistência de um tipo de relação governante-governados em que estes últimos, reduzidos ao estado de rebanho, avanço sob o cajado do pastor, na vida intelectual ou social. Ante essa irracionalidade atrasada, só o racionalismo apresenta-se como uma arma eficaz. Como realizar a modernidade sem o auxílio da razão e da racionalidade?" (Abed Al-Jabri, Introdução à Crítica da Razão Árabe, 1999, p. 32-33).

${ }^{32}$ Sobre o tema, vide Lafer, A Reconstrução dos Direitos Humanos: um diálogo com o pensamento de Hannah Arendt, 2001; Lafer, A Internacionalização dos Direitos Humanos, 2005; Almeida, Direitos Humanos e não-violência, 2001; Piovesan, Temas de Direitos Humanos, 2. ed., 2003.
} 
da existência e habitante da mesma globalidade. No sentido de relativizar a ideia de nação como constitutiva da vida dos cidadãos do Estado-nação, no texto Inclusão: integrar ou incorporar?, Habermas afirma: "O nacionalismo, contudo, apesar desse papel catalisador, não é nenhum pressuposto constitutivo de um processo democrático" ${ }^{33}$ Isso significa que a "cidadania democrática contemporânea' não depende da identidade nacional para sobreviver. ${ }^{34}$ Neste ponto, Habermas diverge claramente das teses de Carl Schmitt a respeito da relação entre povo e nação, na base de uma homogeneidade nacional. ${ }^{35}$ E esta forma de 'identidade pós-nacional' que se reclama dentro da ideia de uma cidadania cosmopolita é de fundamental importância para as sociedades pluralistas, complexas e multiculturais contemporâneas. ${ }^{36}$

Se nem Estado, nem democracia e nem cidadania coincidem com a ideia de 'nação', mas são tornadas experiências convergentes com a ideia de 'nação', então, essas experiências podem ser dissociadas sem prejuízo do 'projeto de uma sociedade governada pelo direito nacional', para dar lugar à dimensão e às perspectiva de uma cultura pós-nacional. A solidariedade abstrata criada entre membros de uma mesma sociedade se deve menos a aspectos aos quais normalmente se atribui o maior peso, como cultura, língua, práticas comuns, e mais de procedimentos que solidificam os elos de ligação entre um e outro, parceiros das regras, dada pelas leis e fomentada pela participação política. ${ }^{37} \mathrm{O}$ éthos definido como sentimento de solidariedade nacional não se constitui naturalmente, senão através de um processo dirigido politicamente. Ele não é a manifestação de nenhum sentimento natural, ou de nenhuma tendência óbvia do convívio humano. Ele é tecido e estruturado politicamente, e, enquanto sobrevive, adquire uma incorporação 'natural' à via cotidiana, como se a 'nação' fosse uma expressão presente nos sentimentos de cada cidadão cuja história se vê marcada a essa fidelidade ou a essa identidade. Em O Ocidente dividido, Habermas pode afirmar: "Um tal ethos político não é nada que brote naturalmente. Enquanto resultado de um auto-entendimento político que sempre ocorre simultaneamente a processos democráticos, este ethos realiza-se de forma transparente e apresenta-se, mesmo aos participantes, como algo construído" ${ }^{38}$

\footnotetext{
${ }^{33}$ Habermas, Inclusão: integrar ou incorporar?: sobre a relação entre nação, Estado de Direito e Democracia, in Revista Novos Estudos, 2004, p. 102.

${ }^{34}$ Cf. Rochlitz, Habermas: o uso público da razão, 2005, p. 132-133. A respeito, afirma Said: “...a noção de uma identidade nacional homogênea, coerente, unificada é a mais repensada, e essa mudança está sendo sentida em toda esfera da sociedade e da política" (Said, Humanismo e Crítica Democrática, 2007, p. 44).

${ }^{35}$ Habermas cita em específico a Teoria da Constituição (Verfassungslehre) de Schmitt para contestá-la em sua substância. Vide Habermas, Inclusão: integrar ou incorporar?: sobre a relação entre nação, Estado de Direito e Democracia, in Revista Novos Estudos, 2004, p. 103-107.

${ }^{36}$ Cf. Habermas, Inclusão: integrar ou incorporar?: sobre a relação entre nação, Estado de Direito e Democracia, in Revista Novos Estudos, 2004, p. 102.

${ }^{37}$ Rochlitz, Habermas: o uso público da razão, 2005, p. 132.

${ }^{38}$ Habermas, O Ocidente Dividido, 2006, p. 83-84.
} 
Num contexto de profundas transformações sócio-políticas isto fica ainda mais evidente. Com a aceleração de transformações sob o signo da globalização, deve-se apontar a dissociação destes elementos como condição importante para a continuidade do processo de integração mundial. Neste contexto, é inegável o fato de o 'Estado-nação' estar sendo conduzido a um novo desafio, a saber, o desafio de uma requalificação de sua existência à luz das exigências de uma comunidade internacional cada vez mais presente no cotidiano das atividades nacionais. A noção de 'cidadania cosmopolita' deve ser capaz de acompanhar a nova dinâmica de constituição de laços identitários e solidários. ${ }^{39}$ É a formação cada vez mais acentuada de um 'mundo da vida' mutuamente compartilhado por indivíduos que pertencem a uma mesma comunidade de risco.

"A soberania do Estado, antes indivisível, agora está sendo fatiada em pedaços cada vez mais finos e espalhada por todo o espaço continental ou mesmo planetário", na percepção sociológica de Zygmnut Bauman, traduz um pouco esta sensação do tempo. ${ }^{40} \mathrm{Com}$ isso, o modo de conformação westfaliano do 'Estado-nação' começa a ceder em direção a novos modelos e a novas experiências que falam a linguagem da integração. É claro que isto acirra movimentos contraditórios e antagônicos, conduzindo a tendências, de um lado, ao retorno à identidade fundada na solidariedade cultural, e, de outro lado, à abertura em direção a uma comunidade expandida de interesses. De uma forma ou de outra, o Estado-nação passa por uma experiência de transformação que deve ser notada quando se trata de discutir o futuro do próprio nacionalismo e dos conceitos que tradicionalmente organizaram tanto as ciências sociais, quanto a própria cultura dos direitos. ${ }^{41}$

\subsection{Os Riscos do Relativismo Absoluto e a Retomada Política da Cultura das Identidades}

A retomada da cultura das identidades traduz uma sensação de desconforto, no ambiente global, como retorno ou retomada das raízes. Não por outro motivo, o crescimento da intolerância, do fanatismo religioso, das tendências de retomada das doutrinas puras, ou ainda, das heranças tradicionais, tem encontrado solo fértil para o seu desenvolvimento. A partir daí, é possível esperar atitudes e comportamentos que neguem direitos humanos e que afirmem a intolerância como linguagem de convívio global; no refluxo da globalização, dá-se também um processo de reenvio da cultura às suas origens, momento em que as sublevações diversas e as cargas de cultura ganham novamente um significado político. Esse significado tem sido

\footnotetext{
${ }^{39}$ Como acontece sob a experiência, ainda em germinação, da cidadania europeia: "Considera-se cidadão da União qualquer pessoa que tenha a nacionalidade de um Estado-membro, sendo que a cidadania europeia não anula nem substitui a cidadania nacional de qualquer cidadão de um estado-membro da UE, antes acresce a ela" (Avelãs Nunes, A Constituição Européia e os Direitos Fundamentais, in Verba luris, v. 5, $\mathrm{n}^{\circ} 5,2006$, p. 386).

${ }^{40}$ Bauman, Vida Líquida, 2007, p. 62.

${ }^{41}$ Cf. Rochlitz, Habermas: o uso público da razão, 2005, p. 115.
} 
desenvolvido como uma forma de resistência dos povos e culturas oprimidos, diante das pressões do neoliberalismo consumista, da reificação desenfreada do convívio humano, da homogeneização cultural e da globalização econômica. ${ }^{42}$

Esse 'uso resistente' das culturas é algo que se opõe ao localismo globalizado, gerando uma tensão na opção entre globalização ou retomada das raízes culturais. A tensão se expressa na relação entre a 'homogeneidade da globalização' e a 'heterogeneidade das culturas', estas últimas resistentes ao localismo globalizado. $\mathrm{Na}$ análise do sociólogo português Boaventura de Souza Santos, especificamente no texto intitulado Por uma concepção multicultural dos direitos humanos, pode-se encontrar a seguinte percepção do problema: "A reemergência dos direitos humanos no final do século $X X$, início do século XXI, é hoje entendida como sinal da volta do cultural e até mesmo do religioso. Ora, falar de cultura e de religião é falar de diferença, de fronteiras, de particularismos". ${ }^{43}$ Por isso, para contrastar à esta ideia, a preparação do cosmopolitismo, em sua concepção, aparece como forma de resistência, e, portanto, expressa " $\ldots$ a solidariedade transnacional entre grupos explorados, oprimidos ou excluidos pela globalização hegemônica" ${ }^{44}$

O tema é complexo e envolve inúmeras atitudes que começam a identificar a forma de aparição de políticas de realização fragmentada dos direitos humanos, considerada a dispersão dos grupos, movimentos, religiões, culturas, formas de vida, e diversas constituições da humanidade. Maio de 68 pode ser identificado como momento histórico de retomada destas identidades fragmentadas e apagadas pela forma de vida moderna. ${ }^{45}$ De uma certa forma, a homogeneidade moderna, que havia apagado as diferenças, agora é retomada como expressão de um orgulho auto-afirmador. O destrinchamento da dimensão da diversidade e da cultura, expõe, no entanto, suas forças, que vem ganhando significações políticas contestatórias e evocativas de um passado perdido, soterrado pelas forças entrópicas da vida moderna. É, sem dúvida alguma compreensível que, numa dimensão psicológica, “...essa reação defensiva se alimente de fontes espirituais as quais colocam em movimento, contra a força secularizada do Ocidente, um potencial que já parece ter desaparecido. O recurso furioso dos fundamentalistas a um conjunto de crenças - nas quais a modernidade não acarretou qualquer processo de aprendizado auto-reflexivo nem qualquer diferenciação entre religião, conhecimento secular e política - ganha uma certa plausibilidade porque essas crenças se nutrem de uma substância que aparentemente desapareceu no Ocidente", como afirma Habermas. ${ }^{46}$

\footnotetext{
${ }^{42}$ A respeito do tema das novas solidariedades, no contexto da economia globalizada, vide Faria, 2004 , p. 267.

${ }^{43}$ Santos, Reconhecer para Libertar, 2003, p. 432.

${ }^{44}$ Santos, Reconhecer para Libertar, 2003, p. 432.

${ }^{45}$ A respeite, consulte-se Bittar, O Direito na Pós-modernidade e Reflexões Frankfurtianas, 2009.

${ }^{46}$ Habermas, Fundamentalismo e Terror, in Filosofia em Tempo de Terror (Giovanna Borradori), 2004, p. 45. Ainda uma vez, Habermas retoma se manifesta sobre o tema, em outro texto:
} 
'Políticas culturais', 'reconhecimento da diferença', 'direito à diferença', 'iguais na diferença' tem sido termos e expressões comumente utilizados para designar aquilo que estas exigências exprimem, re-codificadas nos termos de uma linguagem dos direitos humanos, considerada a condição particular de cada humano em sua singularidade (idoso, criança, mulher, negro), para ficar na dimensão de alguns diplomas normativos recentes e concretos (Estatuto do Idoso, Estatuto da Criança e do Adolescente, Lei Maria da Penha, Estatuto da Igualdade Racial).

Por isso, o debate contemporâneo, no campo dos direitos humanos não deixa de se traduzir na dimensão de um debate filosófico, que expõe a tensão entre liberdade, igualdade e reconhecimento. Em verdade, na concepção filosófica de Axel Honneth, não apenas a ideia de uma oposição absoluta entre demandas culturais e demandas materiais é falsa, como também a ideia de que estes movimentos são novos parece-lhe também falsa: "Assim como é impossível reduzir os movimentos de hoje inspirados por uma 'política de identidade' a objetivos culturais justos, os movimentos tradicionais de resistência do final do século IX e do início do século XX também não podem ser reduzidos a meras demandas materiais ou legais". 47 De toda forma, a reemergência do problema da cultura re-situa o debate sobre a dinâmica dos processos de afirmação da pessoa, seja por sua estima pessoal, seja por suas habilidades, seja por suas necessidades, seja por suas diferenças. O debate sobre a garantia e a realização dos direitos ganha, sem dúvida alguma, em complexidade, neste ambiente, em que, ao lado das ideias de liberdade e igualdade, a ideia de diferença passa a figurar no quadro de exigências valorativas vetoriais da cultura política contemporânea.

É importante expor o risco de que a sobrevalorização da ideia de diferença pode significar um passo no sentido do esclarecimento das identidades culturais e do resgate das origens, mas também, pode significar dois passos atrás no sentido da intolerância e do extremismo diferenciador que opõe iguais a não-iguais enquanto pertencentes ou não a certas identidades. Somente o uso cauteloso da ideia de diferença consegue dar condições de

\footnotetext{
"Denominamos fundamentalistas a los movimientos religiosos que, bajo las restricciones cognitivas de las condiciones de la vida moderna, propagan o incluso practican el retorno a la exclusividad de las posiciones de fé de carácter premoderno" (Habermas, Un Diálogo sobre lo Divino y lo Humano, in Israel o Atenas, 2001, p. 188). E, mais recentemente: "O atual fundamentalismo religioso que pode ser observado dentro e fora dos muros do cristianismo, confere inusitada atualidade, triste, à intenção daquela crítica da religião" (Habermas, Entre Naturalismo e Religião: estudos filosóficos, 2007, p. 237). No mesmo sentido de afirmar os perigos da intolerância religiosa, afirma Said: "O entusiasmo religioso é talvez a mais perigosa das ameaças ao empreendimento humanista, porque é patentemente anti-secular e antidemocrático por natureza, e na sua forma monoteísta como uma espécie e política é por definição quase tão intolerantemente desumano e totalmente indefensável quanto é possível ser" (Said, Humanismo e Crítica Democrática, 2007, p. 74).

${ }^{47}$ Honneth, Reconhecimento ou Redistribuição? A mudança de perspectivas na ordem moral da sociedade, in Teoria Crítica no Século XXI (Souza; Mattos, orgs.), 2007, p. 80.
} 
produção de uma cultura capaz de integrar a diferença e a diversidade, dentro da perspectiva da igualdade de todos. Os riscos que decorrem deste tipo de emancipação fragmentária são os de criação de uma 'guetização por identidades'. ${ }^{48}$ Nesse passo, a advertência de Terry Eagleton, em $A$ ideia de cultura, é de significativa importância: "Se essas subculturas protestam contra as alienações da modernidade, também as reproduzem na sua própria fragmentação". ${ }^{49}$

$\mathrm{Na}$ mesma medida destas observações, o tratamento dos debates sobre identidade e povo, no capítulo Antropologia e ética, do livro Mal-estar na modernidade, Sergio Paulo Roaunet discute a ideia de que as teorias relativistas infantilizam o tratamento das culturas e precarizam a condição do desenvolvimento e da autonomia dos grupos que procura estudar e proteger. ${ }^{50}$ Nesta perspectiva, o convívio entre os diferentes não tem solução, como bem afirma o antropólogo social Robert Rowland ${ }^{51}$ Ego e alter decidem não conviver, e não trocar; se o relativismo cultural é levado ao seu extremo, ou seja, ao relativismo absoluto, ainda que esta expressão represente um paradoxo em si, o resultado é a intolerância. Se a advertência sobre a relatividade das culturas é de fundamental importância para que se evite o etnocentrismo, como adverte o texto seminal de Claude Lévi-Strauss, Raça e história, ${ }^{52}$ é de todo relevante que se destaque a necessidade de formação de alternativas de trânsito e interações entre as culturas. Onde toda perspectiva de uma moralidade a ser exercida como patrimônio comum cede ante a ideia da identidade cultural, o relativismo absolutiza e insula a dimensão do exercício de cada cultura.

Assim, o relativismo absoluto, ou o particularismo cego, funcionam como forças identitárias alienadoras do convívio. Ainda que a resistência à homogeneidade genérica seja de fundamental importância para a salvaguarda da diferença, a 'guetização' é o outro extremo ao qual o relativismo pode conduzir a ação social. Por isso, as propostas relativistas querem ver em cada

\footnotetext{
${ }^{48}$ Bauman, Comunidade, 2003, p. 127.

${ }^{49}$ Eagleton, A Idéia de Cultura, 2005, p. 66. Os perigos desta fragmentação se vêem espelhados na realidade urbana de um grande número de capitais do mundo: "O próximo pouso é em Berlim. A coruja observa, com nojo, cenas de violência semelhantes às que ocorreram na véspera da Segunda Guerra. As vítimas, agora, são imigrantes turcos, negros e vietnamitas" (Rouanet, Mal-estar na Modernidade: ensaios, 1993, p. 47).

50 "As duas teses relativistas - a da determinação integral pela cultura e a incomensurabilidade das culturas - bloqueiam todas as vias para a mudança" (Rouanet, Mal-estar na Modernidade, 1993, p. 272).

51 "Contrapor ao etnocentrismo o relativismo cultural ou a compreensão de outras culturas nos seus próprios termos não é assim uma solução. O relativismo cultural levado até às suas últimas consequências torna cada cultura incompreensível a todas as outras, isolando-a no seu próprio campo de significações. Só a tradução entre culturas, ou o estabelecimento de um código antropológico de tradução inter-cultural, poderia romper o círculo. Mas a tradução - qualquer tradução - tem as suas regras e as suas exigências" (Rowland, Antropologia, História e Diferença, 3. ed., 1997, p. 16-17).

${ }^{52}$ Lévi-Strauss, Antropologia Estrutural Dois, 4. ed., 1993, p. 328-366.
} 
cultura uma entidade intocável, exatamente como forma e garantia de se manter a estrutura viva da relação entre cultura e identidade local. Assim, o discurso relativista acaba por negar validade a toda forma de intromissão cultural e por representar uma força de reação a toda forma de integração, aproximação, ou intervenção, mesmo as de caráter humanitário, na medida em que este discurso vê na cultura uma antropologia natural em processamento. Nem o estupro de mulheres, nem o enforcamento em praça pública, nem a perseguição a minorias, nem as diversas formas de genocídio poderiam ser avaliadas como violações dos direitos humanos, na perspectiva de um relativismo absoluto.

Nos estudos contemporâneos de teoria constitucional, o tema vem ganhando grande relevo. A partir de influências que se podem extrair da teoria do discurso, aproveitando a expressão 'patriotismo constitucional', cunhada a princípio pelo jurista alemão Dolf Sternberg, e amplamente difundida por Habermas mais recentemente, a percepção de que a multiplicidade de visões de mundo é simultaneamente válida vem ganhando força e reconhecimento. ${ }^{53}$ Assim, no lugar das tradições que apelam a condições locais de desenvolvimento cultural, o apelo a princípios e regras contidos na Constituição permite a formação de um convívio pluralista, identificado pela unidade da norma constitucional, marco fundamental da integração social e da garantia da diversidade no convívio. Por isso, uma cultura política, fundada sobre princípios constitucionais, "...não depende necessariamente de uma origem étnica, lingüística e cultural comum a todos os cidadãos". Isto permite a Habermas afirmar que uma política liberal apenas significa "...o denominador comum de um patriotismo constitucional (Verfassungspatriotismus) capaz de agudizar, não somente o sentido para a variedade, como também a integridade das diferentes e coexistentes formas de vida de uma sociedade multicultural". ${ }^{54}$

Neste sentido, fica claro que não é necessário amarrar a 'cidadania democrática' à 'identidade nacional' de um povo; porém, prescindindo da variedade de diferentes formas de vida culturais, ela exige a socialização de todos os cidadãos numa 'cultura política comum', ${ }^{55}$ quando a conversão do 'etnonacionalismo' em 'patriotismo constitucional' ${ }^{56}$ parece significar um

\footnotetext{
${ }^{53}$ Cf. Cattoni, Direito, Política e Filosofia: contribuições para uma teoria discursiva da constituição democrática no marco do patriotismo constitucional, 2007, p. 01.

54 "Entgegen einem weit versbreiteten Missverständnis heißt Verfassungspatriotismus, dass sich Bürger die Prinzipien der Verfassung nicht allein in ihren abstrakten Gehalt, sondern konkret aus dem geschichtlichen Kontext ihrer jeweils eigenen nationalen Geschichte zu eigen machen" tradução: "Contradizendo um mal-entendido amplamente difundido, patriotismo constitucional significa que os cidadãos se apropriam dos princípios da Constituição não apenas em seu teor abstrato, mas concretamente, a partir do contexto histórico da própria história nacional de cada país" (Habermas, Ratzinger, Dialektik der Säkularisierung, 2006, p. 25).

${ }^{55}$ Habermas, Direito e Democracia, II, 2003, p. 289.

${ }^{56}$ Cf. Habermas, Inclusão: integrar ou incorporar?: sobre a relação entre nação, Estado de Direito e Democracia, in Revista Novos Estudos, 2004, p. 129-130. A busca de novas rotas para a
} 
importante passo no sentido da afirmação da 'cultura cosmopolita', e, nesse sentido, um elemento de transição importante para a realização dos ideais de uma sociedade internacional fundada em princípios de 'justiça cosmopolita' ${ }^{57}$

Para cá parece se deslocar o novo esforço, da cultura pós-nacional e da construção de formas de vida capaz de convívio com a diferença e de integração social a partir de similaridades democrático-cidadãs. Aqui, mais uma vez, se a cultura pode ser colocada a serviço de alguma causa, se habilita a ser um elemento agregador, no sentido de uma 'civilização mundial', enquanto convívio das diferenças e originais características de cada identidade cultural, no atribuído à expressão por Lévi-Strauss. ${ }^{58}$ Ainda que alguns teóricos contemporâneos, como Axel Honneth, discordem da ideia de Habermas, afirmando ser preferível falar em "personalidade multicultural" do que propriamente em "personalidade cosmopolita", na medida em que o desaparecimento do 'Estado-nação' não será tão rápido e tão simples como se possa imaginar, ${ }^{59}$ não se desmerece a importância deste aceno filosófico que resgata a ideia kantiana do cosmopolitismo como um apontamento de fundamental importância no contexto da formação de uma cultura pós-nacional.

\section{DIÁLOGO E COSMOPOLITISMO: DESAFIOS DA CULTURA PÓS-NACIONAL}

Se nos tópicos anteriores foi possível identificar e perceber os riscos do nacionalismo integral, no qual cidadãos podem ser mergulhados em direção ao extremismo, e do relativismo absoluto, no qual cidadãos podem ser mergulados em direção à guetização cultural, a capacidade de trânsito passa a ser uma exigência significativa para a formação da 'personalidade cosmopolita'.

cidadania faz parte da sensação ameaçadora que paira contra a identidade do Estado-nação nos tempos hodiernos, chamados de líquidos, por Zygmunt Bauman: "Um novo consenso sobre cidadania ("patriotismo constitucional", para usar um termo de Jürgen Habermas) não pode ser construído atualmente da maneira como o era não faz muito tempo - mediante a garantia de proteção constitucional contra os caprichos do mercado, famoso por dilapidar as posições sociais e por sabotar os direitos à estima social e à dignidade pessoal. A integridade do corpo político em sua forma atualmente mais comum de Estado-nação está em apuros, e assim é necessário procurar urgentemente uma legitimação alternativa" (Bauman, Tempos Líquidos, 2007, p. 20-21).

57 "Unter Staatsbürger entsteht eine wie immer auch abstrakte und rechlich vermittelte Solidarität erst dann, wenn die Gerechtigkeitsprinzipien in das dichtere Geflecht kultureller Werstorientierungen Eingang finden" - tradução: "Entre cidadãos de um mesmo país surge, como sempre, uma solidariedade abstrata e legalmente mediada somente quando os princípios de justiça conseguem penetrar na densa entrançadura dos valores culturais" (Habermas, Ratzinger, Dialektik der Säkularisierung, 2006, p. 25).

58 “.... consideramos a noção de civilização mundial como uma espécie de conceito limite, ou como maneira abreviada de designar um processo complexo. Pois se nossa demonstração é válida, não há, não pode haver uma civilização mundial num sentido absoluto que geralmente se atribui a este termo, porque a civilização implica a coexistência de culturas oferecendo entre si o máximo de diversidade, e consiste mesmo nesta coexistência. A civilização mundial só poderia ser a coligação, em escala mundial, de culturas, preservando cada qual sua originalidade" (Lévi-Strauss, Antropologia Estrutural Dois, 4. ed., 1993, p. 363).

${ }_{59}$ Cf. Honneth, Entrevista, in Galisi Filho, Escola de Frankfurt: a nova geração, Entrevista, in Folha de São Paulo, Caderno Mais!, domingo, 22 de junho, 2001, p. 06. 
Por isso, aproveitando o legado cosmopolita da tradição moderna, Sergio Paulo Roaunet, em diálogo com o antropólogo Roberto Cardoso de Oliveira, indica ao pensamento contemporâneo a via do diálogo extraído da teoria do discurso de Jürgen habermas como de fundamental importância para o equacionamento entre os extremos do relativismo e da globalização, abrindo caminhos para uma linha de antropologia, que se batiza de antropologia comunicativa. ${ }^{60}$ As observações da antropóloga Ana Lúcia Pastore Schritzmeyer seguem esta linha de preocupações: "No limite, a antropologia, que compartilha valores gerados no mesmo contexto do qual nasceram os princícios que regem os direitos humanos, pode - e a meu ver, deve - posicionar-se criticamente em relação a esses direitos, valendo-se de um respeito sensível, dosado, diante das potencialidades e limitações dos interlocutores que se predispõem a dialogar". ${ }^{6}$

As sociedades abertas e plurais, tolerantes e compreensivas, capazes de absorver a diversidade e conviver com as diferenças, exige, do ponto de vista religioso, que crentes e não-crentes estejam em pé de igualdade. ${ }^{62} \mathrm{O}$ elo entre crentes e não-crentes dá-se pelos canais do diálogo. Essa ideia afirma uma perspectiva de ação social que trabalhe num nível de entendimento que se superpõe às crenças de cada um, singularmente considerado. Cidadãos de sociedades livres e plurais têm de respeitar a localidade da crença de cada qual, ao mesmo em que se realizam num território comum, que se dá no plano do diálogo e das oportunidades iguais de fala. Por isso, o solo do qual brotam as possibilidades de respeito aos diversos direitos humanos se finca sobre duas importantes escoras: o diálogo e o cosmopolitismo. ${ }^{63}$

\footnotetext{
60 A discussão desse tema e a proposta de uma antropologia comunicativa se encontram desenvolvidas no capítulo 9, Antropologia e ética, em Mal-estar na Modernidade, 1993, p. 255-293. 61 "Em outras palavras, a própria antropologia, justamente devido a seu percurso inicialmente atrelado ao colonialismo, pergunta-se até que ponto defender valores contidos nos direitos humanos - um arranjo cultural típico do mundo ocidental moderno, sistematizado especialmente a partir do humanismo do século XVIII e da Revolução Francesa - não é uma nova forma de impor esse valores aos mais diferentes modos de ser, pensar e agir"(Schritzmeyer, Ana Lúcia Pastore, Antropologia e educação em direitos humanos, in Educação e metodologia para os direitos humanos (Bittar, Eduardo C. B., org.), 2008, p. 121).

62 "Toleranzverständnis von liberal verfassen pluralistischen Gesellschaften mutet nicht nur den Gläubigen im Umgang mit Ungläubigen und Andersgläubigen die Einsicht zu, dass sie vernünftigerweise mit dem Fortbestehen eines Dissenses zu rechnen haben. Auf der anderen Seite wird diselbe Einsicht im Rahmen einer liberalen politischen Kultur auch Ungläubigen im Umgang mit Gläubigen zugemulet" - tradução livre: "A compreensão tolerante das sociedades pluralistas compostas de forma liberal exige não apenas dos crentes, no trato com incrédulos e professantes de outras crenças, o reconhecimento de que devem contar racionalmente com a continuação de uma dissensão. Por outro lado, esse mesmo reconhecimento é exigido de incrédutlos, no trato com crentes, no contexto de uma cultura política liberal" (Habermas, Ratzinger, Dialektik der Säkularisierung, 2006, p. 35).

63 "El Estado constitucional cooperativo es aquel Estado que de forma activa se ocupa de los demás Estados, se ocupa también de las demás instituciones nacionales y supranacionales, así como igualmente de los ciudadanos de sus respectivos países, ciudadanos que ya no le son en modo alguno extraños, del mismo modo en que su apertura a todo lo relativo al medio ambiente
} 
A noção de diálogo, emergente no debate sobre a relação entre as culturas, ${ }^{64}$ é um caminho fundamental para o desenvolvimento de condições de atrelamento político, para que desta política interna internacional se torne possível a articulação do convívio global fundado numa paz permanente entre os povos e numa forma institucionalizada de resolução dialogada de conflitos internacionais. ${ }^{65}$ Neste sentido, o diálogo aparece como um mecanismo de criação das condições de exercício da justiça dos povos. O diálogo pressupõe, como ferramenta de mudança, a aceitação de parâmetros mínimos a serem construídos entre as culturas, como pontes de relacionamento fundamentais para a articulação da relação circular eu-outro/outro-eu, o que por si só demanda a superação do relativismo, em direção à valorização de formas integradoras de constituição das formas de relação intersubjetiva. ${ }^{66}$

O diálogo carece de condições concretas de facilitação do convívio e da troca simbólica. Os vários empecilhos existentes, como a não equivalência dos horizontes do mundo da vida, a distância territorial, a diferença dos costumes locais, a língua como reveladora de identidades culturais enraizadas localmente, entre outros, motivam a que se pense também nos modos de processamento deste diálogo. ${ }^{67}$ Acima de tudo, a linguagem da insegurança

se convierte en una apertura al mundo" (Häberle, Pluralismo y Constitución: estudios de Teoría Constitucional de la sociedad abierta, 2002, p. 259).

${ }^{64}$ Apontando para estes rumos, os estudos interdisciplinares entre antropologia e direitos humanos, a exemplo da pesquisa desenvolvida por Peruzzo, Pedro Pulzatto. Direitos Humanos, Povos Indígenas e Interculturalidade. Dissertação de Mestrado. Faculdade de Direito. Universidade de São Paulo. São Paulo, 2011.

${ }^{65}$ De onde se extrai a interelação entre democracia e paz, um direito à paz, nas palavras de Bonavides, inspirado em Kant: "Direito à paz, sim. Mas paz em sua dimensão perene, à sombra do modelo daquele filósofo. Paz em seu caráter global, em sua feição agregativa de solidariedade, em seu plano harmonizador de todas as etnias, de todas as culturas, de todos os sistemas, de todas as culturas, de todos os sistemas, de todas as crenças e que a fé e a dignidade do homem propugnam, reivindicam e sancionam" (Bonavides, O Direito à Paz, Folha de São Paulo, 03 de dezembro de 2006, A3).

${ }^{66}$ Da mesma opinião é o historiador Peter Demant: "O relativismo cultural-moral impossibilita qualquer avaliação do fenômeno, assim como a idéia de que todas as opiniões têm igual valor também impede um diálogo sério entre o Ocidente e muçulmanos modernistas" (Demant, O Mundo Muçulmano, 2004, p. 338).

${ }^{67}$ Parte-se, para construir esta reflexão, das opiniões de Habermas sobre o tema, quando discute a questão dentro do âmbito da União Européia: "No interior da União existem atualmente treze idiomas diferentes, oficialmente reconhecidos. Esse pluralismo de linguagens parece constituir, à primeira vista, obstáculo intransponível para a criação de uma comunidade política com as dimensões da Europa. No entanto, o poliglotismo oficial da política da União Européia é a expressão inalienável de um reconhecimento recíproco da integridade e do igual valor das diferentes culturas nacionais. Ora, sob o manto desse garantia, é tanto mais fácil praticar o inglês como língua de trabalho, sempre que os respectivos partidos não dispuserem de outro idioma comum. Pode-se acrescentar que certos países menores, tais como a Holanda, a Dinamarca, a Suécia e a Noruega, constituem bons exemplos para um sistema escolar que estabeleceu o inglês como segundo idioma principal para toda a população" (Habermas, Era das Transições, 2003, p. 142). "Através da História, a distribuição dos idiomas pelo mundo refletiu a distribuição do poder no mundo. Os idiomas mais falados - inglês, mandarim, espanhol, francês, árabe, russo - são ou foram os idiomas de Estados imperiais, que promoveram ativamente o uso de seus 
e a lógica da ação estratégica devem ceder lugar para a formação de um ambiente internacional que possibilite, pela segurança, o incremento na aposta da compreensão e do diálogo. "A segurança é uma condição necessária do diálogo entre culturas. Sem ela, há pouca chance de que as comunidades venham a abrir-se umas às outras e a manter uma conversa que venha a enriquecê-la e a estimular a humanidade de sua união. Com ela, as perspectivas da humanidade parecem brilhar". ${ }^{68}$

A questão do diálogo está extremamente associada à questão de como é que se desenvolveram espaços favoráveis ao processo de implementação de liberdades de expressão e opinião. Neste sentido, não há diálogo possível sem que exista uma arena onde os interesses, aflições, sentimentos, opiniões, valores possam ser expostos num debate público que forma as condições para o estabelecimento de um discurso produtor de consensos e decisões comuns. Neste sentido, há de se dizer que a esfera pública mundial (Weltöffentlichkeit) já se encontra em formação, e para que ela se estabeleça "(...) basta a indignação moral, consensual em relação a violações flagrantes da proibição do uso de força e dos direitos humanos. Hoje já podemos observar, em status nascendi, as estruturas comunicativas de uma esfera pública mundial que se fazem necessárias para isso; também já se delineiam disposições culturais para reações" ${ }^{69}$

O diálogo deverá produzir, como seu fruto, o incremento das condições de solidarização por interesses e causas comuns. Por isso, é impossível pensar o futuro da própria ideia de cosmopolitismo se for pensada somente a criação de instrumentos jurídicos e formais de racionalização do convívio mundial, já profundamente estratificado e definido segundo condições crescentes de desigualdade e injustiça. Por isso, para que se pense o diálogo como instrumento de inclusão, é fundamental que se pense acima de tudo no diálogo como formador das condições de incremento da solidariedade cosmopolita, como afirma Habermas em A constelação pós-nacional: "Uma regulação da sociedade mundial desencadeada exige políticas que distribuam os prejuízos. Isso só será possível com base em uma solidariedade cosmopolita até o momento inexistente que, sem dúvida, terá uma qualidade de ligação mais fraca que a solidariedade civil surgida no interior dos Estados nacionais. Objetivamente, a população mundial uniu-se já há algum tempo de modo involuntário em uma comunidade de risco. Daí não parecer tão implausível a

idiomas por outros povos. Mudanças na distribuição do poder produziram mudanças no uso de idiomas" (Huntington, O Choque de Civilizações e a Composição da Ordem Mundial, 1997, p. 73). No entanto, fica claro também que, apesar de falada por um número significativo de habitantes do planeta, o mandarim não poderia se tornar a língua franca das relações internacionais, na medida em que é estranho a $92 \%$ das pessoas do mundo. Esta é a opinião de Huntington, O Choque de Civilizações e a Composição da Ordem Mundial, 1997, p. 70.

${ }^{68}$ Bauman, Comunidade, 2003, p. 128.

69 Habermas, O Ocidente Dividido, 2006, p. 83; Vide, também, Habermas, Entre Naturalismo e Religião: estudos filosóficos, 2007, p. 381. 
expectativa de que sob essa pressão ocorra a continuação daquela grande virada abstrata, historicamente cheia de conseqüências, que fez a consciência local e dinástica fosse sucedida por uma nacional e democrática". ${ }^{70}$

\section{CONCLUSÕES}

A transição do Estado nacional ao Estado pós-nacional merece acenos que melhor definam as tarefas do convívio internacional, em busca da justiça pós-nacional. Para que esta possa prosperar, é necessário que a consciência cosmopolita e a cultura do respeito aos direitos humanos, num processo de troca social que valorize o respeito, o cuidado e a consideração, estejam fundados na ideia de que a comunidade de riscos comuns da humanidade foi lançada a desafios comuns, que somente poderão ser vencidos por esforços comuns. A integração social baseada na solidariedade, na intercompreensão e no diálogo, para a teoria do discurso, formam o cerne o agir comunicativo. Por isso, essa perspectiva teórica não está alinhada com a ideia do conservadorismo antropológico-cultural, ou ainda, com a ideia da intocabilidade das culturas (relativismo absoluto), mas prevê a modificação a ser provocada nas culturas pelos canais do diálogo, onde a linha de assinatura de interação vem marcada pela necessidade de reconhecimento de que a racionalidade da interação pela comunicação entrecorta o papel do convívio social. ${ }^{71} \mathrm{O}$ diálogo é, por excelência, um instrumento de transformação (individual e social), pois implica na troca mútua e no compartilhamento de visões de mundo diferentes. Assim, o trânsito entre a diferença de ego e a diferença de alter carece de ser posta na dimensão dos canais da comunicação, como forma de expressão dos meios pelos quais as controvérsias, os conflitos e as diferenças ganham a possibilidade de convívio.

Os desafios políticos contemporâneos, a desenfreada globalização, a hegemonia cultural levaram à retomada identitária, cujos efeitos podem ser detectados pelos diversos refluxos que sinalizam pela idolatria das identidades. A identidade se traduz na forma de vida que estabelece condições para o relativismo absoluto, cujos riscos para a composição de uma cultura cosmopolita são grandes, na medida em que a ideia de cultura não pode conduzir os grupos de uma mesma sociedade a diferenciações que tornem impossível o reconhecimento mútuo por direitos comuns, e nem de grupos de países ou culturas diferentes se guetizaram num auto-cerramento que representa uma

\footnotetext{
${ }^{70}$ Habermas, A Constelação Pós-nacional, 2001, p. 73-74.

${ }^{71}$ Nesse sentido, Wolff afirma: "Com efeito, o que vem a ser uma cultura 'bárbara' (e, portanto, uma cultura 'civilizada'), de acordo com nossa definição? Chamaremos de bárbara toda cultura que não disponha, em seu próprio cerne, de estruturas que lhe permitam admitir, assimilar ou reconhecer outra cultura, ou seja, a simples possibilidade de outra forma de humanidade. Também chamaremos de bárbaro, consequentemente, todo costume ou toda prática que, qualquer que seja a cultura específica a que pertença, tem como finalidade ou efeito negar uma forma específica de existência humana" (Wolff, Quem é Bárbaro?, in Civilização e Barbárie (Novaes, org.), 2004, p. 41).
} 
forma de negação da abertura para o convívio com a alteridade das demais comunidades globais.

Assim, a ideia de relativismo absoluto é um passo negativo na perspectiva de afirmação de uma cultura cosmopolita, como o retorno aos nacionalismos também o é. Não em outra dimensão, os direitos humanos somente podem encontrar condições para seu desenvolvimento na dinâmica de sociedades capazes de cultivar espaços políticos capazes de identificarem cidadãos por traços políticos democráticos comuns, que ainda assim, tragam os potenciais de convívio das diversas formas de vida integradas em suas instituições. Por isso, os riscos de uma globalidade integrada envolve um conjunto de esforços da cultura, das ciências, das instituições políticas e das religiões, no sentido de proporcionar condições para a formação da consciência e da solidariedade cosmopolitas.

\section{BIBLIOGRAFIA}

ABED AL-JABRI, Mohammed. Introdução à Crítica da Razão Árabe. Tradução Roberto Leal Ferreira e Mamede Mustafá Jarouche. São Paulo: UNESP, 1999.

ALMEIDA, Guilherme Assis de. Direitos Humanos e Não-violência. São Paulo: Atlas, 2001.

BAUMAN, Zygmunt. La Globalización: consecuencias humanas. Tradução de Daniel Zadunaisky. 2. ed., México: Fondo de Cultura Económica, 2001.

. Europa: uma aventura inacabada. Tradução de Carlos Alberto Medeiros. Rio de Janeiro: Jorge Zahar, 2006.

. Comunidade: a busca por segurança no mundo atual. Tradução de Plínio Dentzien. Rio de Janeiro: Jorge Zahar, 2003. Zahar, 2007.

Vida Líquida. Tradução de Carlos Alberto Medeiros. Rio de Janeiro: Jorge

. Tempos Líquidos. Tradução de Carlos Alberto Medeiros. Rio de Janeiro: Jorge Zahar, 2007.

BITTAR, Eduardo C. B. O Direito na Pós-modernidade e Reflexões Frankfurtianas.

2. ed., Rio de Janeiro: Forense Universitária, 2009.

BONAVIDES, Paulo. O Direito à Paz, in Folha de São Paulo, Tendências e Debates, São Paulo, Domingo, A3, 03 de dezembro de 2006.

CATTONI, Marcelo. Direito, Política e Filosofia: contribuições para uma teoria discursiva da constituição democrática no marco do patriotismo constitucional. Rio de Janeiro: Lumen Júris, 2007.

DEMANT, Peter. O Mundo Muçulmano. São Paulo: Contexto, 2004.

. Os Dilemas dos Muçulmanos na Europa, in Panorama da Conjuntura Internacional, Informativo do Grupo de Conjuntura Internacional da USP, $n^{\circ} 39$, ano 10, p. 01-03, out./nov. 2008.

EAGLETON, Terry. A Idéia de Cultura. Tradução de Sandra Castello Branco. São Paulo: UNESP, 2005.

ELIAS, Norbert. O Processo Civilizador: uma história dos costumes. Apresentação Renato Janine Ribeiro. V. I, Tradução de Ruy Jungman. Rio de Janeiro: Jorge Zahar, 1994. 
. O Processo Civilizador: formação do Estado e civilização. Apresentação Renato Janine Ribeiro. V. II. Tradução de Ruy Jungman. Rio de Janeiro: Jorge Zahar, 1993.

FARIA, José Eduardo. O Direito na Economia Globalizada. São Paulo: Malheiros, 2004. FRASER, Nancy. Reconhecimento sem Ética? in Teoria Crítica no Século XXI (SOUZA, Jessé; MATTOS, Patrícia, orgs.), São Paulo, AnnaBlume, p. 113-140, 2007.

GALISI FILHO, José. Escola de Frankfurt: a nova geração, Entrevista, in Folha de São Paulo, Caderno Mais!, domingo, 22 de junho, p. 05-07, 2001.

GROSSI, Miriam Pillar. Antropologia e Direitos Humanos: um campo consolidado, in Antropologia e Direitos Humanos, $\mathrm{n}^{\circ} 04$ (GROSSI, Miriam Pillar; HEILBORN, Maria Luiza; MACHADO, Lia Zanotta), Blumenau, Nova Letra, p. 07-10, 2006.

HABERMAS, Jürgen. O Estado-nação Europeu frente aos Desafios da Globalização: o passado e o futuro da soberania e da cidadania, in Revista Novos Estudos, Tradução de Antonio Sérgio Rocha, São Paulo, CEBRAP, nº 43, p. 87-101, nov. 1995.

. Más allá del Estado Nacional. Tradução de Manuel Jiménez Redondo. México: Fondo de Cultura Económica, 1998.

. Inclusão: integrar ou incorporar? Sobre a relação entre nação, Estado de Direito e Democracia, in Revista Novos Estudos, CEBRAP, Tradução de Luciano Codato, São Paulo, nº 52, p. 99-120, 1998.

Bestialidade e Humanidade: uma guerra no limite entre direito e moral, in Cadernos de Filosofia Alemã, Tradução de Luiz Repa, Departamento de Filosofia, São Paulo, Universidade de São Paulo, v. 5, p. 77-87, ag. 1999.

. Por que necesita Europa una Constitución?, in Dialogo Científico, Revista Semestral de Investigaciones Alemanas sobre Sociedad, Derecho y Economia, Centro de Comunicación Científica con Ibero-América, Buenos Aires, v. 10, nº 1/2, p. 35-44, 2001.

. Israel o Atenas: ensayos sobre religión, teología y racionalidad. Traducción de Eduardo Mendieta. Madrid: Trotta, 2001.

A Constelação Pós-nacional: ensaios políticos. Tradução de Márcio Seligmann-Silva. São Paulo: Littera Mundi, 2001.

. A Inclusão do Outro: estudos de teoria política. Tradução de George Sperber;

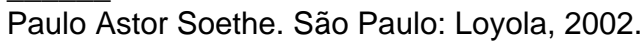

. Direito e Democracia: entre facticidade e validade. v. I, 2. ed., Tradução de Flávio Beno Siebeneichler. Rio de Janeiro: Tempo Brasileiro, 2003.

Direito e Democracia: entre facticidade e validade. v. II, 2. ed., Tradução de Flávio Beno Siebeneichler. Rio de Janeiro: Tempo Brasileiro, 2003.

. Era das Transições. Tradução de Flávio Beno Siebeneichler. Rio de Janeiro: Tempo Brasileiro, 2003.

. Fundamentalismo e Terror, in Filosofia em Tempo de Terror: diálogos com Habermas e Derrida (Giovanna Borradori), Tradução de Roberto Muggiati, Rio de Janeiro, Jorge Zahar, p. 37-55, 2004.

. Diagnósticos do Tempo: seis ensaios. Tradução de Flávio Beno Siebeneichler. Rio de Janeiro: Tempo Brasileiro, 2005. 
Es aún Posible el Proyecto Kantiano de la Constitucionalización del Derecho Internacional?, in Derecho y Justicia en una Sociedad Global, Anales de la Cátedra Francisco Suárez, International Association for Philosophy of Law and Social Philosophy, Universidad de Granada, Granada, 2005, p. 101-126, mayo 2005.

. O Ocidente Dividido. Tradução de Luciana Villas-Bôas. Rio de Janeiro: Tempo Brasileiro, 2006.

. Entre Naturalismo e Religião: estudos filosóficos. Tradução de Flávio Beno Siebneichler. Rio de Janeiro: Tempo Brasileiro, 2007.

. Ay, Europa! Pequeños Escritos Políticos. XI. Traducción de José Luiz López de Lizaga. Madrid: Trotta, 2009.

HÄBERLE, Peter, Pluralismo y Constitución: estudios de Teoría Constitucional de la sociedad abierta. Traducción de Emilio Mikunda. Madrid: Tecnos, 2002.

HONNETH, Axel. Luta por Reconhecimento: a gramática moral dos conflitos sociais. Tradução de Luiz Repa. São Paulo: Editora 34, 2003.

, Reconhecimento ou Redistribuição? A mudança de perspectivas na ordem moral da sociedade, in Teoria Crítica no Século XXI (SOUZA, Jessé; MATTOS, Patrícia, orgs.), São Paulo, AnnaBlume, p. 79-94, 2007.

HUNTINGTON, Samuel. O Choque das Civilizações e a Recomposição da Ordem Mundial. Tradução de M. H. C. Côrtes. Rio de Janeiro: Objetiva, 1997.

IANNI, Octávio. A Era do Globalismo. 8. ed., Rio de Janeiro: Civilização Brasileira, 2004. KANT DE LIMA, Roberto (org.), Antropologia e Direitos Humanos. n n 03 . Niterói: EDUFF, Associação Brasileira de Antropologia, 2001.

LAFER, Celso. A Reconstrução dos Direitos Humanos: um diálogo com o pensamento de Hannah Arendt. São Paulo: Companhia das Letras, 2001.

. A Internacionalização dos Direitos Humanos: constituição, racismo e relações internacionais. São Paulo: Manole, 2005.

LÉVI-STRAUSS, Claude. Antropologia Estrutural Dois. 4. ed., Tradução de Maria do Carmo Pandolfo. Rio de Janeiro: Tempo Brasileiro, 1993.

LINDGREN ALVES, José Augusto, Cidadania, Direitos Humanos e Globalização, in Direitos Humanos, Globalização Econômica e Integração Regional: desafios do direito constitucional internacional, São Paulo, Max Limonad, p. 77-96, 2003.

MARCUSE, Herbert. Comentários para uma Redefinição de Cultura, in Cultura e Sociedade, v. 2, Tradução de Robespierre de Oliveira, São Paulo, Paz a Terra, p. 153-175, 1998.

Sobre o Caráter afirmativo da Cultura, in Cultura e Psicanálise, 3. ed., Tradução de Wolfgang Leo Maar, Robespierre de Oliveira, Isabel Loureiro, São Paulo, Paz e Terra, p. 07-68, 2001.

MERCIER, Paul. História da Antropologia. Tradução de Claudia Menezes. São Paulo: Moraes, s. d.

PERUZZO, Pedro Pulzatto. Direitos Humanos, Povos Indígenas e Interculturalidade. Dissertação de Mestrado. Faculdade de Direito. Universidade de São Paulo. São Paulo, 2011.

PIOVESAN, Flávia. Temas de Direitos Humanos. 2. ed., São Paulo: Max Limonad, 2003. 
ROCHLITZ, Rainer (coord.). Habermas: o uso público da razão. Tradução de Lea Novaes. Rio de Janeiro: Tempo Brasileiro, 2005.

ROUANET, Sergio Paulo. As Razões do Iluminismo. São Paulo: Companhia das Letras, 1987.

. Mal-estar na Modernidade: ensaios. São Paulo: Companhia das Letras, 1993.

ROWLAND, Robert. Antropologia, História e Diferença: alguns aspectos. 3. ed., Porto: Afrontamento, 1997.

SAID, Edward. Orientalismo: o Oriente como invenção do Ocidente. Tradução de Tomás Rosa Bueno. São Paulo: Companhia das Letras, 1990.

Humanismo e Crítica Democrática. Tradução de Rosaura Eichenberg. São Paulo:

Companhia das Letras, 2007.

SCHRITZMEYER, Ana Lucia Pastore. Nossos Muros e os dos outros, in Antropologia Extramuros: novas responsabilidades sociais e política dos antropólogos, 2008, p. 173-178.

Antropologia e Educação em Direitos Humanos, in Educação e Metodologia para os Direitos Humanos (Bittar, Eduardo C. B., org.), 2008.

SOUZA SANTOS, Boaventura de. Reconhecer para Libertar: os caminhos do cosmopolitismo multicultural. Rio de Janeiro: Civilização Brasileira, 2003.

TOSI, Giuseppe. Guerra e Direito no Debate sobre a Conquista da América, in Verba Iuris: Anuário da Pós-Graduação em Direito, João Pessoa, Universidade Federal da Paraíba, Ano 5, nº 05, p. 277-320, jan./dez. 2006.

; BITTAR, Eduardo C. B. (orgs.). Democracia e Educação em Direitos Humanos numa época de Insegurança. Brasília: ANDHEP; SEDH, UNESCO, UFPB, 2008.

WOLFF, Francis, Quem é Bárbaro?, in Civilização e Barbárie (Novaes, Adauto, org.), São Paulo, Companhia das Letras, p. 19-44, 2004. 